Original Research Article

\title{
Evaluation of anti-lipoxygenase activity of Cassia fistula linn leaves using in vitro methods
}

\author{
Anju Gopi ${ }^{1 *}$, Manju Jisho
}

${ }^{1}$ Department of Pharmacology,

${ }^{2}$ Department of Analysis, Sri

Rama Krishna Institute of Paramedical Sciences, College of Pharmacy, Coimbatore, Tamil Nadu, India

Received: 30 July 2018 Accepted: 13 August 2018

\section{*Correspondence to:}

Dr. Anju Gopi,

Email: mukeshb4816@

gmail.com

Copyright: (C) the author(s), publisher and licensee Medip Academy. This is an openaccess article distributed under the terms of the Creative Commons Attribution NonCommercial License, which permits unrestricted noncommercial use, distribution, and reproduction in any medium, provided the original work is properly cited.

\begin{abstract}
Background: Numerous plants are claimed to possess anti-inflammatory phytoconstituents in folk medicine, however, one among them is Cassia fistula linn leaves. The tree is 6-9 $\mathrm{m}$ high with straight trunk and smooth bark. It is pale green when young and gets rough and dark when old. The leaves are $23-30 \mathrm{~cm}$ long and have got 4-8 pairs of oblong leaflets. Due to lack of specific scientific reports regarding its use for its anti-lipoxygenase property, this particular plant was selected for this particular study with the aim to bring scientific evidence for its therapeutic use.

Methods: The anti-lipoxygenase study as carried by using 5-lipoxygenase(5LOX) assay and 12-lipoxygenase(12-LOX) assay. In both the methods, absorbance of various concentrations of the tests and the control solutions were measured at $234 \mathrm{~nm}$.

Results: Preliminary phytochemical study showed the presence of flavonoids, glycosides, tannins and phenolics. It was found that both the 5-LOX and 12-LOX were inhibited by the extract with a 50\% inhibitory concentration (IC50) of $6.23 \mathrm{mg} / \mathrm{ml}$ obtained for the 5-LOX assay and an IC50 of $3.22 \mathrm{mg} / \mathrm{ml}$ attained for the 12-LOX assay.

Conclusions: The methanolic extract of the plant's leaves showed antilipoxygenase activity similar to Indomethacin, thus ensuring that it could be used as an effective anti-inflammatory medicine.
\end{abstract}

Keywords: Anti-lipoxygenase, Anti-inflammatory, Methanolic leaf extract, 50\% inhibitory concentration

\section{INTRODUCTION}

Inflammation or phlogosis is a pathophysiological response of our living tissues to various injuries that can lead to local accumulation of plasmatic fluids and blood cells. Inflammatory diseases are a main cause of morbidity of the working population, throughout the world. Although it is a defence mechanism taking part in the inflammatory reaction, it can induce, maintain or aggravate many diseases. $^{1}$ Cassia fistula linn belonging to family Caesalpiniaceae has been used for years, traditionally, by tribals and locals in India for the treatment of various inflammatory conditions like the diseases of the heart, leprosy, inflammation, as antipyretic, in rheumatism, in kapha, skin diseases, liver complaints, diseases of the eye, throat trouble and chest complaints. ${ }^{2}$ Preliminary phytochemical screening of the methanolic extract of the leaves as carried out andthe presence of flavonoids, glycosides, tannins and phenolics were detected.

Cycloxygenase and lipoxygenase are the two enzymes involved in the process of inflammation. Cycloxygenase and lipoxygenase willact on arachidonic acid converting them to prostaglandins and lipid hydroperoxide products, which are the inflammatory mediators. Inhibition of these inflammatory enzymes would help to control the process of inflammation. ${ }^{3,4}$ Most of the studies are carried to test if 
the drug can inhibit the cycloxygenase enzyme, where as the main objective of this study is to find the antilipoxygenase activity of the methanolic extract of Cassia fistula linn. Since there is no scientific evidence or researches carried on this plant for its anti-lipoxygenase activity, the extract was subjected to 5-lipoxygenase assay and 12-lipoxygenase assay, using Indomethacin as the control.

\section{METHODS}

\section{Preparation of the methanol extract of Cassia fistula linn leaves}

Earthy materials sticking to the leaves were removed by thoroughly washing with water. The leaves were then made to dry by keeping in shade, then powdered using a mechanical grinder and sieved through No.20 mesh sieve. Cold maceration process was used to prepare methanol extract of the leaves. $15 \mathrm{~g}$ of finely powdered leaves wastaken and triturated with small volume of methanol in a mortar. A total volume of $150 \mathrm{ml}$ of methanol was added and stirred continuously in a mechanical shaker for 4 hours. It was then kept aside for 24 hours. It was again stirred in mechanical shaker for 4 hours kept aside for 12 hours. The contentwas taken and filtered through muslin cloth, after which the filtrate was decanted and evaporated to dryness. ${ }^{4}$

\section{Preliminary phytochemical screening}

Methanolicleaf extract was subjected to qualitative phytochemical tests for determining the presence of various phytoconstituents. ${ }^{5-7}$

\section{A 5-Lipoxygenase inhibition assay}

The method 5-lipoxygenase activity was carried to find out whether methanolic extract of Cassia fistula linn leaves inhibits 5-LOX. The enzyme converts the linoleic acid to its corresponding hydroxylinoleic acid. Here the absorbance of the formed hydroperoxylinoleic acid was measured at 234nm. 5-LOX was purchasedfrom Bangalore Sales Corporation, Azad Nagar, Bangalore. If there is a decrease in the absorbance, then it reflects the inhibition of 5-LOX enzyme, which prevents the conversion of linoleic acid to 5-hydroperoxylinoleic acid.0.2M borate buffer, $\mathrm{pH} 9$ and $0.01 \%$ linoleic acid have to be prepared. Dissolve 5-LOX at a concentration of $5 \mathrm{mg} / \mathrm{ml}$ with ice cold buffer. Immediately dilute with ice cold buffer to yield $300 \mu \mathrm{g} / \mathrm{ml}$. $1 \mathrm{ml}$ of various test solutions of different concentrations varying from $1 \mathrm{mg} / \mathrm{ml}$ to $64 \mathrm{mg} / \mathrm{ml}$ were dissolved in $0.25 \mathrm{ml}$ of enzyme solution $(20,000 \mathrm{U} / \mathrm{ml})$ taken in different test tubes and incubated for $5 \mathrm{~min}$ at $25^{\circ} \mathrm{C}$. To each test tube, $1.0 \mathrm{ml}$ of linoleic acid solution $(0.6 \mathrm{mM})$ was added, mixed well and absorbance was measured at $234 \mathrm{~nm}$. Indomethacin was used as the reference standard. The percentage inhibition was calculated from following equation..$^{8,9}$
$\%$ Inhibition $=($ Absorbance of control-Absorbance of test sample $) \div$ Absorbance of control $\times 100$

\section{A 12-Lipoxygenase inhibition assay}

The inhibition of the 12-lipoxygenase enzyme (12-LOX) prevents the conversion of linoleic acid to 12hydroperoxylinoleic acid. A spectrometric assay for the determination of LOX activity was used. The reaction mixture with a final volume of $2 \mathrm{ml}$ contained $50 \mathrm{mM}$ TrisHCL buffer ( $\mathrm{pH} 8.5$ ), 100mg of enzyme protein and a linoleic acid solution, were prepared in solubilised state. $1 \mathrm{ml}$ of test solutions of various concentrations varying from $1 \mathrm{mg} / \mathrm{ml}$ to $64 \mathrm{mg} / \mathrm{ml}$ was dissolved in to the incubation mixture in different test tubes. The LOX activity was monitored, showingan increase of the absorbance measured at $234 \mathrm{~nm}$, which reflects the formation of hydroperoxylinoleic acid. ${ }^{10,11}$

\section{$\%$ Inhibition $=($ Absorbance of control-Absorbance of test sample $) \div$ Absorbance of control $\times 100$}

The inhibitory effect of compounds tested was expresses as $\mathrm{IC}_{50}$. Percentage of enzyme activity inhibition was calculated, where extinction coefficient of $25 \mathrm{mM}^{-1} \mathrm{~cm}^{-}$ ${ }^{1}$ was used for calculation of enzyme activity.

\section{RESULTS}

\section{Preparation of plant extract}

Extract of Cassia Fistula linn leaves was carried using methanol as solvent. The percentage yield of the methanol extract of the leaves of Cassia Fistula linn was found to be $16.4 \% \mathrm{w} / \mathrm{w}$.

\section{Preliminary phytochemical screening}

Preliminary phytochemical screening of leaves of Cassia fistula linn, indicated the presence of flavonoids, glycosides, tannins and phenolics.

\section{A 5-lipoxygenase inhibition assay of methanol extract of Cassia fistula linn}

Methanol extract of Cassia fistula linn was studied for 5lipoxygenase inhibition activity at various concentrations of $1,2,4,8,16,32$ and $64 \mathrm{mg} / \mathrm{ml}$. The absorbance of the mixture was measured at $234 \mathrm{~nm}$. In Table 1 it can be observed that there is a dose dependent increase in the percentage inhibition. At the concentration of $1 \mathrm{mg} / \mathrm{ml}$ it inhibited the 5-lipoxygenase to $8.39 \%$. Increase in inhibition reached to $72.83 \%$ at a concentration of $64 \mathrm{mg} / \mathrm{ml}$. An $\mathrm{IC}_{50}$ of $6.23 \mathrm{mg} / \mathrm{ml}$ was obtained. Indomethacin was used as the standard. The same concentrations as that of the methanol extract were used. The percentage inhibition was found to be $23.84 \%$ at the concentration of $1 \mathrm{mg} / \mathrm{ml}$. This inhibition increased to $85.35 \%$ at a concentration of $64 \mathrm{mg} / \mathrm{ml}$. It showed an $\mathrm{IC}_{50}$ of $3.22 \mathrm{mg} / \mathrm{ml}$. 


\section{A 12-lipoxygenase inhibition assay of methanol extract of Cassia fistula linn}

The methanol extract of Cassia fistula linn leaves of various concentrations ranging from 1 to $32 \mathrm{mg} / \mathrm{ml}$ was used. From the Table 2, it can be seen that the leaf extract showed an inhibition of $11.03 \%$ at a concentration of $1 \mathrm{mg} / \mathrm{ml}$. The absorbance was found to decrease, which reflected an increase in percentage inhibition.

The extract exhibited anti-lipoxygenase activity with an $\mathrm{IC}_{50}$ value of $7.1 \mathrm{mg} / \mathrm{ml}$. Indomethacin was used as the standard. The same concentrations of $1,2,4,8,32 \mathrm{mg} / \mathrm{ml}$ as that of the methanol extract were used.

The standard showed an inhibition of $7.78 \%$ at a concentration of $1 \mathrm{mg} / \mathrm{ml}$ which then gradually increased to $81.49 \%$ at $32 \mathrm{mg} / \mathrm{ml}$. The $\mathrm{IC}_{50}$ value of the extract was found to be greater than that of standard. The standard showed an $\mathrm{IC}_{50}$ of $6.5 \mathrm{mg} / \mathrm{ml}$.
Table 1: 5-lipoxygenase inhibition assay of methanol extract of Cassia fistula linn.

\begin{tabular}{|c|c|c|c|}
\hline Group & $\begin{array}{l}\text { Dose } \\
(\mathrm{mg} / \mathrm{ml})\end{array}$ & $\%$ inhibition & $\begin{array}{l}\mathrm{IC}_{50} \\
(\mathrm{mg} / \mathrm{ml})\end{array}$ \\
\hline \multirow{7}{*}{ Leaf extract } & 1 & $8.390 \pm 2.907$ & \multirow{7}{*}{$6.23 \pm 0.34$} \\
\hline & 2 & $22.380 \pm 4.22$ & \\
\hline & 4 & $43.970 \pm 5.501$ & \\
\hline & 8 & $55.460 \pm 5.501$ & \\
\hline & 16 & $59.243 \pm 8.225$ & \\
\hline & 32 & $65.927 \pm 1.424$ & \\
\hline & 64 & $72.83 \pm 1.654$ & \\
\hline \multirow{7}{*}{ Indomethacin } & 2 & $41.663 \pm 8.395$ & \multirow{7}{*}{$3.22 \pm 0.87$} \\
\hline & 4 & $63.633 \pm 0.6170$ & \\
\hline & 8 & $66.283 \pm 1.108$ & \\
\hline & 1 & $23.843 \pm 5.070$ & \\
\hline & 16 & $72.854 \pm 2.481$ & \\
\hline & 32 & $78.237 \pm 0.1301$ & \\
\hline & 64 & $85.350 \pm 2.98$ & \\
\hline
\end{tabular}

All determinations were carried out in triplicate manner and values are expressed as the mean \pm SEM

Table 2: 12-lipoxygenase inhibition assay of methanol extract of Cassia fistula linn.

\begin{tabular}{|c|c|c|c|c|}
\hline Group & Dose (mg/ml) & Enzyme activity & \%inhibition & $\mathrm{IC}_{50}(\mathrm{mg} / \mathrm{ml})$ \\
\hline \multirow{6}{*}{ Leaf extract } & 1 & $2.817 \pm 0.043$ & $11.037 \pm 1.357$ & \multirow{6}{*}{$7.1 \pm 0.34$} \\
\hline & 2 & $2.570 \pm 0.106$ & $18.85 \pm 3.345$ & \\
\hline & 4 & $1.943 \pm 0.1133$ & $38.66 \pm 3.576$ & \\
\hline & 8 & $1.381 \pm 0.0597$ & $64.37 \pm 1.913$ & \\
\hline & 16 & $0.976 \pm 0.0069$ & $69.187 \pm 0.213$ & \\
\hline & 32 & $0.77 \pm 0.101$ & $75.69 \pm 3.182$ & \\
\hline \multirow{6}{*}{ Indomethacin } & 1 & $2.932 \pm 0.100$ & $7.787 \pm 3.078$ & \multirow{6}{*}{$6.5 \pm 0.74$} \\
\hline & 2 & $2.612 \pm 0.045$ & $17.503 \pm 1.380$ & \\
\hline & 4 & $1.960 \pm 0.103$ & $43.647 \pm 8.47$ & \\
\hline & 8 & $1.129 \pm 0.060$ & $64.37 \pm 1.913$ & \\
\hline & 16 & $0.8913 \pm 0.229$ & $75.917 \pm 0.213$ & \\
\hline & 32 & $0.5863 \pm 0.057$ & $81.49 \pm 1.825$ & \\
\hline
\end{tabular}

All determinations were carried out in triplicate manner and values are expressed as the mean \pm SEM

\section{DISCUSSION}

Here the study has been carried out for exploring the pharmacological activities and for carrying out the phytochemical screening of the selected Indian plant Cassia fistula linn belonging to family Caesalpiniaceae. Traditionally this plant was used before to treat various inflammatory conditions.

Phytochemical screening of the leaves showed the presence of flavonoids, phenolics, tannins and glycosides. Flavonoids are found to be a group of polyphenolic compounds responsible for the various biological effects as anti-inflammatory, antihepatotoxic and antiulcer. ${ }^{1,2}$
Lipoxygenases forms a family consisting of non-heme iron-containing enzymes. These enzymes catalyzes the polyenic fatty acids like the arachidonic acid to its corresponding lipid hydroperoxideproducts. ${ }^{12,13}$ Glucocorticoids inhibit the release of arachidonic acid from membrane lipids, indirectly reducing the production of eicosanoids- prostaglandins, thromboxanes and leukotrienes. ${ }^{14,15}$ As NSAIDS and glucocorticoids have side effects which is not advisable for chronic conditions, an alternative solution has to be found out. Various studies have been carried out to test the anti-inflammatory(anticycloxygenase) activity of Cassia fistula linn leaves, but anti-lipoxygenase study has never been performed on this plant. ${ }^{16,17}$ Inhibition of Cycloxygenase enzymes alone would result in the availability of the entire arachidonic 
acid for the lipoxygenases to produce leukotrienes. So, it becomes really essential to find an effective anti lipoxygenase product. ${ }^{14,15}$

The methanol extract of Cassia fistula linn leaves was used for testing its anti-lipoxygenaseactivity. 5-LOX and 12LOX activity was tested here. The method, 5-lipoxygenase activity was based on inhibition of 5-LOX enzymes by the methanolic leaf extract. The enzyme converts the linoleic acid to its corresponding hydroperoxylinoleic acid. Here the absorbance of formed hydroperoxylinoleic acid was measured at $243 \mathrm{~nm}^{8}$. The inhibition of LOX is dose dependent. In other words, as the concentration of MCF increases, the formation of the hydroperoxylinoleic acid is decreased, which is reflected as the decrease in absorbance at $234 \mathrm{~nm} .{ }^{11}$ The decrease in the absorbance is due to the inhibition of the conversion of the linoleic acid to 5hydroperoxylinoleic acid, which reflects the inhibition of 5-LOX enzyme. 12-LOX activity is also based on the same principle.

In this the extract was found to inhibit conversion of linoleic acid to 12-hydroperoxylinoleic acid, which reflects the inhibition of 12-lipoxygenase enzyme. Methanoic leaf extract inhibited 5-LOX at a lower concentration than when compared to inhibition of 12 LOX. However, inhibitions in both cases were lesser than that of the standard, Indomethacin.

\section{CONCLUSION}

In conclusion, there has been a growing interest in the alternative medicine and the therapeutic properties of the natural products derived from plants in the years. The leaves of Cassia fistula linn leaves were extracted with methanol and phytochemical screening was carried out with the extract. The leaf extract was found to contain flavonoids, glycosides, tannins and phenolics. Based on the results of various in vitro methods carried out, it can be concluded that Cassia fistula linn possess antiinflammatory activity. Further studies are to be performed using in vivo models to confirm these activities and to find out the exact mechanism by which the plant constituents act.

\section{ACKNOWLEDGEMENTS}

Authors would like to express their sincere gratitude and appreciation to God Al mighty for the love, power, and strength he gave. It is by his encouragement that they could complete this dissertation and they gratefully thank their family for their constant, prayers, encouragement, magnificent support, love and patience throughout the years of education.

Authors take this opportunity to render their profound sense of gratitude, indebtedness ans respectful regards to the esteemed teacher and Mr. A. T. Sivashanmugam, M.Pharm., Department of Pharmacology for his excellent suggestions, kind encouragement and able guidance throughout the course of my work.

Funding: No funding sources

Conflict of interest: None declared

Ethical approval: Not required

\section{REFERENCES}

1. Smyth EM, Burke A, Fitzgerald GA. Lipid-derived autacoids: eicosanoids and platelet-activating factor. In: Brunton LL, Lazo JS, Parker KL, eds. Goodman and Gilman's The Pharmacological Basis of Therapeutics. $11^{\text {th }}$ Ed. New York, NY: McGra-Hill; 2005:653-670.

2. Krithikar KR, Basu BD. Indian medicinal plants. $2^{\text {nd }}$ Ed. Dehradun: International book distributors; 1987:856-860.

3. Guyton AC, Hall JE. Text book of medical physiology. Inflammation: Role of neutrophils and macrophages. $11^{\text {th }}$ Ed. Philadelphia: Elsevier Saunders; 2006:434-437.

4. Umamahesari M, AsokKumar K, Somasundaram A, Sivashanmugam T, Subhadradevi, Ravi TK. Xanthine oxidase inhibitory activity of some medicinal plants. J of Ethnopharmacol. 2007:8(3)547-51.

5. Folkerts G, Kloek J, Muijsers RBR, Nijkamp FP. Reactive nitrogen and oxygen species in airway inflammation. Eur J Pharmacol. 2001;7(4):251-62.

6. Houghton PJ. Traditional plant medicines as a source of new drugs. In: Evans WC eds. Trease and Evans Pharmacognosy. $16^{\text {th }}$ Ed. New York: Elsevier: 2009:62-74.

7. Khandelal KR. Practical Pharmacognosy: techniques and experiments. $12^{\text {th }}$ Ed. Pune: Nirali Prakashan; 2004:150-156.

8. Kumaraswamy MV, Satish S. Free radical scavenging activity and lipoxygenase inhibition of Wood for diafructicosakurz and Butelautilis wall. African J Biotechnol. 2007:7(6)312-8.

9. Shinde UA, Kulkarni KR, Phadke AS, Nair AM, Mungantiar AA, Dikshit, et al. Mast cell stabilizing and lipoxygenase inhibitory activity of Cedarusdeodoro (Roxb). Loud. wood oil. Indian J Expe Biol. 1999; 32(5):258-61.

10. Kemal C, Louis-Flamberg P, Krupinsky-Oslen R, Shorter AL. Reductive inactivation of soya bean lipoxygenase I by catechols: a possible mechanism for regulation of lipoxygenase activity. Biochemistry. 1987;26(9):7064-72.

11. Rackova L, Oblozinsky M, Kostalova D, Kettmann V, Bezakova L. Free radical scavenging activity and lipoxygenase inhibition of Mahoniaaquifolium extract and isoquinolin alkaloids. J Inflamma. 2007;4(15):415.

12. Brash AR. Lipoxygenases: Occurrence, functions, catalysis and acquisition of substrate. The $\mathrm{J}$ Biol Chemi. 1999;274(10):23679-82.

13. Yu C, Chen Y, Cline GW, Zhang D, Zong H, Wang Y, et al. Mechanism by which fatty acids inhibit 
activation of insulin receptor substrate-1 (IRS)associated phosphatidylinositol 3-kinase activity in muscle. The J Bio Chemi. 2002;277(22):50230-6.

14. Satoskar RS, Bhandarkar SD, Rege NN. Pharmacology and pharmacotherapeutics. 20 $0^{\text {th }} \mathrm{Ed}$ Mumbai: Popular prakashan private limited; 2007:160-180.

15. Tripathi KD. Essentials of Medical Pharmacology. $5^{\text {th }}$ Ed. New Delhi: Jaypee Brothers Medical Publishers; 2004:167-184.

16. Gobianand K, Vivekanandan P, Pradeep K, Mohan CVR, Karthikeyan S. Anti-inflammatory and antipyretic activities of Indian Medicinal Plant, Cassia Fistula Linn in Wistar Albino rats. Int J Pharmacol. 2010;6(5):719-25.

17. Mohini AP, Manohar JP, Knode A, Pravin DC, Bhoomi P. In vivo and Invitro screening of medicinal plants for their anti-inflammatory activity. J Appl Pharm Scie. 2012;2(6):19-33.

Cite this article as: Gopi A, Jisho M. Evaluation of anti-lipoxygenase activity of Cassia fistula linn leaves using in vitro methods. Int J Basic Clin Pharmacol 2018;7:1678-82. 